\title{
SOURCES OF ADMINISTRATIVE LAW: PROBLEMS OF JUDICIAL APPLICATION
}

The article deals with sources of administrative law in case law of Ukraine. The subject of the article is a case-law in Ukraine in the branch of administrative law. Logical methods such as analysis, synthesis, induction and deduction were used in the article. Comparative method allowed to analyze difference between common law and civil law legal systems. It is investigated in the article that not only legal acts, which contain administrative norms should be included to the system of sources of administrative law in Ukraine, but also some acts of judiciary which may influence on validity of administrative legal provisions. The author highlights in the article that legal doctrine, soft law, individual acts cannot be regarded as sources of administrative law as they do not possess norms of administrative law and cannot influence on them and thus cannot be regarded as obligatory sources. Some examples from case law of Ukraine are provided concerning problems of application of sources of administrative law. The author made a conclusion that judges in their decisions apply not only sources of law but also other sources, which have additional and informative meaning. These sources cannot be regarded as obligatory for a court or parties of the case. It is proposed in the article that judges shall to point out these sources and explain their non-obligatory role in every decision they make.

Key words: administrative law, source of administrative law, judicial application, legal norm, case-law.

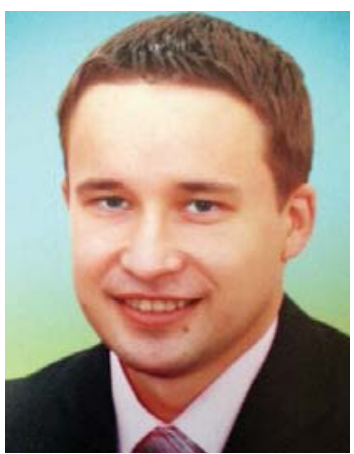

Reshota Volodymyr Volodymyrovych, Ph.D., Associate Professor,

Associate Professor of Administrative and Financial Law Department of Ivan Franko National University of Lviv reshota@icloud.com

\section{Introduction}

Application of relevant sources of law has a big significance for judiciary. For the decision to be legal and justified it should be issued with full conformity with laws and other sources of law. Administrative law is a branch of law which is characterized with huge number of sources which courts shall apply during solving court cases. Except sources of law which are basis for the judgment often judges apply other sources which have influence on their decisions. These sources are not always regarded as sources of law. Although they are applied together with legal norms as a basis for the court's decision. Hence, it's important task to distinguish sources of law and other sources which play only additional role. Administrative law has unique and distinct system of sources of law, which should be applied by relevant subjects of law. It is caused by diversity and huge number of sources of administrative law. There is no single codified act of administrative law in Ukraine and other European countries, except Portugal (Código Administrativo, 1936) which would regulate all 
institutes of administrative law, due to huge sphere of social relationships which are regulated by this branch of law. Instead there are acts which regulate only a particular part of administrative law, for example, Code of Administrative Procedure. The impact of different sources of administrative law on social relationships can be illustrated by examining a case-law of Ukraine.

The aim of this article is to provide scientific analysis of sources of administrative law and underline their features in Ukrainian case-law. The tasks of the article are as following: to analyze notion and essence of "source of administrative law", to find out place of judicial acts in the system of administrative law sources, investigate some problems of application of sources of administrative law in case law of Ukraine.

\section{Notion of the source of administrative law}

There are different elements of system of sources of law. This system differs in every country and legal system. Thus, it's not possible to mechanically adopt sources of law of other country without considering characteristics of every country. Among two main systems of law we should name Anglo-Saxon and Continental system of law. These two systems have different approaches as to the main source of law which judges use for judicial cases settlement. In Anglo-Saxon legal system a precedent as a source of law prevails, while in continental legal system legal acts are traditionally regarded as a main source of law including the administrative law (Pejovic, 2001; Strauss, 2002).

According to the article 129 of the Constitution of Ukraine judges are independent and are guided by the rule of law delivering justice (Konstytutsiia Ukrainy, 1996). Ukraine's Constitution got that provision only in 2016. Before that judge was supposed to be guided by law most likely in a strict meaning. New formulation of constitutional provision is revolutionary for judiciary in Ukraine as it provided constitutional mean for judges to apply not only legislation but also other sources of law. It was quite weird that practice of the European Court of Human Rights was defined as a source of law but there was no constitutional base for doing that. Procedural codes in new edition (2017) also got broader approach as for sources of law which could be applied by judges including the Code of administrative proceedings of Ukraine.

Article 7 of the above-mentioned Code deals with sources of law, which are applied by courts. Although this article regulates only application of the Constitution of Ukraine, other normative acts and international treaties, which are part of Ukraine's legislation. Unfortunately, the article doesn't provide the possibility for administrative courts to apply other sources of law, for example case law of the ECHR, decisions and conclusions of the Constitutional Court of Ukraine, rulings of the Supreme Court etc.

Another problem is that there is no legal act in Ukraine concerning sources of law including normative acts which would regulate their application by relevant subjects.

Sources of administrative law are most commonly described as forms of external sighting of administrative norms. Although it should be pointed out that this definition does not fully reflects all sources which may have or influence on activity of acts which contain norms of administrative law. Hence, we propose to define sources of administrative law as a complex of obligatory legal provisions in written act of a competent subject or subjects, which creates, amends, suspends or abolishes operation of the legal administrative norm (Reshota, 2016). This definition allows us to include to the system 
of administrative law sources also other obligatory regulators of social relationships of public administration. It creates grounds for including some acts of judiciary to the system of administrative law sources.

3. Judicial acts as sources of administrative law

A question may arise why to include to the system of administrative law sources which do not contain administrative norms. In this regard it should be pointed out that judicial decisions do not contain legal norms in Continental law system, but has big influence on existing legal provisions. Among all judicial decisions or acts of judiciary which have big impact on administrative norms in Ukraine we should enumerate: decisions and conclusions of the Constitutional Court of Ukraine, model decisions of the Supreme Court in administrative cases, decisions on application of legal norms which are held in rulings of the Supreme Court and judicial decisions of administrative courts (Supreme Court, appeal administrative courts and district administrative courts) on validity of a certain regulatory acts or their provisions.

Except that we should not to forget about special place in the system of sources of administrative law of Ukraine of practice of the European Court of Human Rights. It should be pointed out that the Law of Ukraine "On execution of decisions and application of practice of the European Court of Human Rights" in Article 17 states that Convention and practice of the Court (ECHR) shall be applied as a source of law (Pro vykonannia rishen ta zastosuvannia praktyky Yevropeiskoho Sud u z prav liudyny, 2006). This underline special place of the case law of the European Court of Human Rights as a source of administrative law, which is established by law. Unfortunately, the Code of administrative proceedings of Ukraine doesn't provide legal basis for application of the practice of European Court of Human Rights as a source of law in the corresponding article. Thus, this article should be amended and include other sources of law which courts may apply solving particular cases. In this relationship we should mention that not a separate decision is recognized as a source of law but practice of the ECHR in general which includes different decisions which provide stability of the European Convention. The case law shouldn't be identified as a separate decision of the court, as the practice includes a number or judicial decisions which create certain legal positions of the court.

\section{Problems of application of sources of administrative law in case law}

One of the latest decisions of the Supreme Court shows the importance and meaning of the European Convention and practice of the European Court of Human Rights. In Supreme Court's ruling of June 20, 2018 in a case no. 514/134/17 it held that appeal court in the case showed too much formality when applied paragraph 15,5 of the Transitional provisions of the Civil Procedure Code of Ukraine. This paragraph states that appeals shall be brought to the court of first instance until new informational system starts to work. Nevertheless, The Supreme Court held that application of this provision violates Article 6 of the Convention and principle of reasonable justice (Seryavin and others v. Ukraine, no. 4909/04, § 58) and principle of proportionality (Postanova Verkhovnoho Sudu, 2018). This legal position of the Supreme Court has big influence and may be applied for administrative and commercial cases. In this way, to our opinion, court made a conclusion how to bypass a law. It is also needed to stress upon the fact that this position of the Supreme Court is not obligatory inter partes of this case, but also should be 
applied by other courts until it is amended by the Great Chamber of the Supreme Court.

It should be mentioned that judicial decisions are not intended to regulate social relationships but to solve the case inter partes. Though often these decisions affect unidentified number of persons who might apply certain legal provision. For example, when administrative court decides that certain legal act is unlawful it may be recognized as void and therefore it will lose its validity not only for parties of the case, but for all subjects of law. In this way the administrative court cannot create a new legal rule, but only abolish legal act or its provisions which contradict to acts, which have higher legal force.

It should be also underlined that not all sources known in theory of law may be regarded as sources of administrative law, for example, legal doctrine, legal customs etc. As these sources may have only additional meaning for a court and parties of the case. At the same time courts often use these «sources» which do not contain administrative norms as a legal ground for their decisions. In some cases, they refer to scientific and practical commentaries on normative acts. For example, in the decision of the judge of the Volnovasky District Court of Donetsk Oblast of March 11, 2015 in the case no. 221/553/15-p it is stated: "According to Article 173 of the Code of Administrative Offenses (hereinafter referred to as the Code), small-scale hooliganism, that is, inappropriate language in public places and other events which, according to a scientific and practical commentary to the Code, includes relieve of oneself in public places which violates a public order" (Postanova suddi Volnovaskoho raionnoho sudu Donetskoi oblasti, 2015). Although reference to the scientific and practical commentary on the Code is disputable due to the fact that it does not possess a legal norm, does not extend or complement the legal regulation. In the above-mentioned example of the judicial decision it is not even indicated the author or authors and the year of the publication of this commentary. Therefore, it cannot be used as a source of law and there should be a reference that a commentary is not a legal ground for the decision, as it can only serve as an additional information. Judicial doctrine is not a source of administrative law that's why reference to the sources of law and other additional sources should be distinguished.

There is another bright example of application of legal doctrine in court's decision. In judgment of the Popasnyansk district court of Luhansk region of April 5, 2017 it is stated that the court considers to appeal to the words of the US Supreme Court judge Steven Breyer, written in his separate opinion (joined by the President of the Court, John and Judge Anthony Kennedy) in the case of Petrella v. Metrogoldwyn-Mayer, Inc., et al.": "Legal systems contain doctrines that help courts avoid injustice that might have arisen if the law was applied strictly in each case, regardless of how unusual the circumstances are. $<\ldots>$ The nature of justice, as Aristotle has noted, is to correct the law when it is defective because of its universality" (Postanova suddi Popasnianskoho raionnoho sudu Luhanskoi oblasti, 2017). This, in turn, allowed the judge to reach an ambiguous conclusion about the possibility of applying administrative penalties smaller than those provided for in the relevant article of the Code of Ukraine on Administrative Offenses, even though this Code does not provide possibility to apply "lesser" penalty, than is provided in the Code. Thus, the judge noted that "it is necessary and sufficient to impose a more lenient administrative penalty than envisaged in Part 1 of Article 164 of the Code, namely in the form of a fine of 170,00 UAH with the confiscation of tobacco products" 
(Postanova suddi Popasnianskoho raionnoho sudu Luhanskoi oblasti, 2017). The reference to a separate opinion of a judge of the Supreme Court of the United States and Aristotle enriches the above-mentioned court's decision, but in such a case, it is necessary to distinguish between references to the legal doctrine and the sources of law on the basis of which the court makes its decision. This requires a better structuring of judicial decisions. In addition, in the above case it would be appropriate to refer to the practice of the ECHR, which indicates that in some cases of administrative offenses are criminal in its nature and fully covered by all guarantees of Article 6 of the Convention for the Protection of Human Rights and Fundamental Freedoms (for instance, paragraphs 21-22 of the decision in the case "Nadtochii v. Ukraine", paragraph 33 of the judgment in the case "Gurepka v. Ukraine").

Article 246.4.5 of the Code of Administrative proceedings of Ukraine states that declaration of the court's decisions shall include norms of law, which applied court and motives for their application. This provision doesn't provide any ground for courts to use sources which do not possess norms of law and therefore are not obligatory. That's why these additional sources, which have only informational meaning, should be separated from legal norms, which are held in source of law. Doing so, courts will clarify which sources they used as a legal ground for their decisions and which sources have only additional meaning. This has also a practical role as incorrect application of norms of material law is a ground for a court of appeal instance to abolish a court's decision fully or partially. Thus, incorrect application of additional sources which are not sources of law cannot be a basis for the decision annulment.

\section{Conclusions}

Analysis of main problems of application of sources of administrative law by Ukrainian courts proves that this issue has not only theoretical but also practical meaning. Sources of law should be regarded not only as acts which contain norms of administrative law, but also include some judicial decisions which may influence on legislation, broader its formulation, abolish legal acts or their provisions. This mean that acts of judiciary should also be considered as sources of administrative law. In some cases, judicial decisions influence not only inter partes (on parties of the case), but also on other subjects of law, for example, abolishing normative act. It should be also stressed that in this way judicial decisions shall correct mistakes and lacunas of legislator or other bodies of public administration. As for other sources, namely: case law, legal doctrine, individual (administrative) acts, legal customs, soft law, administrative contracts etc., they cannot be included to the system of sources of administrative law in Ukraine. These "sources" do not have administrative norms and cannot influence on their validity. Hence these sources may be applied only as additional informative source, which do not have obligatory meaning for parties and for the court itself. It is proposed to highlight these additional nonobligatory sources separately from sources of law, applied by courts. Hence, we should point out that case law does not have the same impact on the legal system of Ukraine as a case-law influence on countries of common law system. Despite that, a convergence of the Romano-Germanic and Anglo-Saxon legal systems, their gradual approximation, interpenetration allows to combine their distinct features to ensure an effective protection of human rights in both systems. 


\section{Bibliography:}

1. Código Administrativo (aprovado pelo Decreto-lei No. 27-424 de 31 de dezembro de 1936). URL: https://www.fd.unl.pt/Anexos/Investigacao/1867.pdf (data de acesso: 25.07.2018).

2. Конституція України: Закон України від 28 червня 1996 р. № 254к/96-ВР / Верховна Рада України. URL: http://zakon2.rada.gov.ua/laws/show/254\%D0\%BA/96-\%D0\%B2\%D1\%80/ print (дата звернення: 22.06.2018).

3. Pejovic C. Civil Law and Common Law: Two Different Paths Leading to the Same Goal. Victoria University of Wellington Review. 2001. Vol. 32. P. 818-840.

4. Strauss P.L. Administrative Justice in the United States. Durham, North Carolina: Carolina Academic Press, 2002. 293 p.

5. Решота В.В. Основні підходи до визначення поняття «джерело адміністративного права». Вісник Національного університету «Львівська політехніка». Серія «Юридичні науки». 2016. № 855. С. 100-108.

6. Про виконання рішень та застосування практики Європейського суду з прав людини: Закон України від 23 лютого 2006 р. № 3477-IV / Верховна Рада України. URL: http://zakon3.rada.gov.ua/laws/show/3477-15/print1510078617636447 (дата звернення: 29.06.2018).

7. Постанова Верховного Суду від 20 червня 2018 р. (справа № 514/134/17) / Єдиний державний реєстр судових рішень. URL: http://www.reyestr.court.gov.ua/Review/74963333 (дата звернення: 11.07.2018).

8. Постанова судді Волноваського районного суду Донецької області від 11 березня 2015 р. (справа № 221/553/15-п) / Єдиний державний реєстр судових рішень. URL: http://reyestr.court.gov.ua/Review/45296714 (дата звернення: 29.06.2018).

9. Постанова судді Попаснянського районного суду Луганської області від 5 квітня 2017 р. (справа № 423/369/17) / Єдиний державний реєстр судових рішень. URL: http://reyestr.court.gov.ua/Review/65910303\# (дата звернення: 02.07.2018).

\section{References:}

1. Código Administrativo (aprovado pelo Decreto-lei No. 27-424 de 31 de dezembro de 1936). Retrieved from: https://www.fd.unl.pt/Anexos/Investigacao/1867.pdf. [in Portuguese].

2. Verkhovna Rada of Ukraine (1996). Konstytutsiia Ukrainy: Zakon Ukrainy [Constitution of Ukraine: the Law of Ukraine]. Retrieved from: http://zakon2.rada.gov.ua/laws/ show/254\%D0\%BA/96-\%D0\%B2\%D1\%80/print.

3. Pejovic, C. (2001). Civil Law and Common Law: Two Different Paths Leading to the Same Goal. Victoria University of Wellington Review, vol. 32, pp. 818-840.

4. Strauss, P.L. (2002). Administrative Justice in the United States. Durham, North Carolina: Carolina Academic Press. [In English].

5. Reshota, V.V. (2016). Osnovni pidkhody do vyznachennia poniattia "dzherelo administratyvnoho prava" [Basic approaches to the definition of "source of administrative law"]. Visnyk Natsionalnoho universytetu "Lvivska politekhnika". Seriia "Yurydychni nauky", no. 855, pp. 100-108.

6. Verkhovna Rada of Ukraine (2006). Pro vykonannia rishen ta zastosuvannia praktyky Yevropeiskoho sudu z prav liudyny: Zakon Ukrainy [On the implementation of the decisions and application of the European Court of Human Rights practice: the Law of Ukraine]. Retrieved from: http://zakon3.rada.gov.ua/laws/show/3477-15/print1510078617636447.

7. Single State Register of Court Decisions (2018). Postanova Verkhovnoho Sudu [Resolution of the Supreme Court] dated 20 June 2018 (case no. 514/134/17). Retrieved from: http://www.reyestr.court.gov.ua/Review/74963333. 
8. Single State Register of Court Decisions (2015). Postanova suddi Volnovaskoho raionnoho sudu Donetskoi oblasti [Resolution of the Judge of the Volnovak District Court of Donetsk Region] dated March 11, 2015 (case no. 221/553/15-p). Retrieved from: http://reyestr.court.gov.ua/Review/45296714.

9. Single State Register of Court Decisions (2017). Postanova suddi Popasnianskoho raionnoho sudu Luhanskoi oblasti [Resolution of the Judge of the Popasnyansk district court of Lugansk region] dated April 5, 2017 (case no. 423/369/17). Retrieved from: http://reyestr.court.gov.ua/Review/65910303\#.

\section{ДЖЕРЕЛА АДМІНІСТРАТИВНОГО ПРАВА: СУДОВА ПРАКТИКА}

\section{Володимир Решота,}

кандидат наук з державного управління, доцент,

доцент кафедри адміністративного та фінансового права

Львівського національного університету імені Івана Франка

reshota@icloud.com

У статті розглядаються деякі проблеми судового застосування джерел адміністративного права судами в Україні. Визначено, щзо до джерел адміністративного права в Україні варто відносити не лише правові акти, щзо містять адміністративні норми, а й деякі акти судової влади, які можуть впливати на чинність адміністративно-правових норм. Підкреслюється, що судова практика, адміністративні акти, адміністративні договори, правова доктрина, правові звичаї та м'яке право не можуть розглядатись як джерела адміністративного права, оскільки вони не містять норми адміністративного права та не можуть впливати на них, а отже, не можуть вважатися загальнообов'язковими. Наводяться деякі приклади судової практики України щзодо проблем застосування джерел адміністративного права. У результаті дослідження автором запропоновано висновки щодо необхідності поділу джерел адміністративного права, які застосовує суд, на джерела права, похідні джерела (судові рішення), а також джерела переконливого характеру, щзо мають лише інформативне, додаткове значення.

Ключові слова: адміністративне право, джерело адміністративного права, судове застосування, правова норма, судова практика. 